\title{
Appearance and Chemical Control of White Mango Scale (Aulacaspis tubercularis) in Central Rift Valley
}

\author{
Gashawbeza Ayalew*, Abiy Fekadu and Birhanu Sisay
}

EIAR, Melkassa Center, Post Box No: 436, Adama, Ethiopia

\begin{abstract}
Occurrence of White Mango Scale (WMS), Aulacaspis tubercularis Newstead (Hemiptera: Diaspididae), in Ethiopia was known in 2010. It had remained confined to western Ethiopia where local mango trees of old age found until recently. Leaf samples infested by the pest were brought to Melkassa Agricultural Research Center (MARC) for diagnosis in June 2014. Hence, a survey to determine occurrence and distribution of the pest on mango orchards in the Central Rift Valley was conducted in August 2014. Four out of seventeen fields surveyed were infested by the pest. Of these infestation in two orchards was $100 \%$. These orchards are located around Batu Degaga and Melkawoba about $10 \mathrm{Km}$ east of MARC. Infestation in the other two orchards was very slight. Leaf infestation in the highly affected orchards ranged between 7 and $85 \%$. As no single insecticide has been registered for use against the pest in Ethiopia, a new systemic insecticide spirotetramat (Movento) obtained from Bayer chemical company in Addis Ababa was tested for its efficacy to control the pest along with Methidathion which is a registered insecticide for the control of Red scale, Aonidiella aurantii (Homoptera: Diaspididae) in citrus and untreated control. The study was conducted at Melkawoba located close to MARC using Randomized complete Block Design (RCBD) with three replications. Treatments were applied using motorized knapsack sprayer. Movento $150 \mathrm{OD}$ and Methidathion $400 \mathrm{EC}$ were applied at 1.7 and $5 \mathrm{ml}$ mixed with three liters of water, respectively biweekly for a total of five times. Number of WMS per ten leaves randomly picked per treatment prior to treatment application was used to assess efficacy of the test insecticide. Number of WMS was similar after the first spray in all the treatments. After the second to fourth spray, WMS number in the untreated plot was consistently higher than the insecticide treatments without significant difference between treatments. After the fifth spray population in the untreated control was significantly higher and nearly ten-fold over the insecticide treatments. Performance of Movento was on par with Methidathion. Percent corrected mortality showed a progressive increase from 36 to $90 \%$ and 49 to $74 \%$ in Movento and Methidathion treatments respectively after the second to fifth spray. The results reported in this study are preliminaries aimed at confirming presence of WMS in the CRV and to test efficacy of Movento against the pest. A study towards integrated management of the pest based on understanding the ecology of the pest need to be conducted. Insecticide screening program should focus on systemic insecticides that are less harmful to the pest's natural enemies similar to Movento considered in this study.

Copyright@2015 STAR Journal, Wollega University. All Rights Reserved.

Article Information Article History:

Received : 26-02-2015

Revised : 13-06-2015

Accepted : 19-06-2015

Keywords:

White mango scale

Central Rift Valley

Movento

Insecticidal control

*Corresponding Author:

Gashawbeza Ayalew

E-mail:

gashawbeza@yahoo.com

\section{INTRODUCTION}

Realizing the importance of agricultural diversification, increasing attention has been given to improving the horticulture sector in Ethiopia. Improved fruit production has been one of the focus areas towards this. Production area of fruit crops is estimated at 61,972 ha (CSA, 2012). Mango ranks third in area of production next to banana and avocado. In production, it ranks 2 nd next to banana. In 2012, fresh mango production level was estimated to be 69, 751 tons (CSA, 2012). Like many other fruits produced in the country, productivity of mango is very low due to unavailability of quality seed/planting materials, poor agronomic practices, damage by resident and invasive pests and poor post harvest handling leading to huge post harvest losses. The Tephritid fruit flies, an enormous threat to fruit production throughout the world

(Mohamed, 2003) have been the only major economically important insect pest of mango in Ethiopia (Tsedeke, 1994, Ferdu et al., 2006). Due to global agriculture and trade coupled with poor quarantine organization, introduction of new disease and insect pests to Ethiopia has become a common phenomenon (PPSE, 2013).

Occurrence of white mango scale, Aulacaspis tubercularis Newstead (Hemiptera: Diaspididae), in Ethiopia was first reported in August 2010 (Mohammed et al., 2012). It had remained confined to western Ethiopia where local mango trees of old age found until recently. It was intercepted from mango seedlings brought from elsewhere in June 2013 at Melkassa Agriculture Research Center (MARC). These were destroyed safely to prevent
\end{abstract}


Gashawbeza Ayalew et alo,

contamination of the existing mango orchard at the center. The insect has not been observed infesting mango trees planted at MARC to date. Leaf samples infested by the pest were brought to MARC by a staff of the Adama district bureau of Agriculture named Eshetu Dessalegne on 26 June 2014 for diagnosis. The samples were brought from mango orchard located at Melkawoba about $10 \mathrm{~km}$ south of MARC. A visit to the orchard was made the following week and $100 \%$ infestation of the available mango trees in the area was noted. A. tubercularis was also intercepted in Tigray region of Ethiopia from seedlings purchased from Arbaminch area of southern Ethiopia for plantation purpose (Gashawbeza, 2014). Hence WMS can no longer be considered a quarantine or regulated non quarantine pest in Ethiopia because of its wide spread presence in the country. Females lay 80 to 200 eggs depending on temperature. After hatching crawlers move to feeding sites settling within 24 hours. Female crawlers settle randomly, male crawlers settle in groups close to females. Up to $80 \%$ of crawlers become males. Leaf defoliation drying of young twigs, pink blemish around the feeding sites on fruit and yellowing on the leaves are typical damage symptoms. under heavy infestation fruit drop prematurelu and become smaller (Abo-Shanab, 2012)

No single insecticide has been registered for WMS control in Ethiopia. Insecticides currently in use against WMS in WMS infested orchards are insecticides recommended for the control of armoured scales such as the red scale (Aonidiella auranti) on citrus in the early 1980s (Tsedeke, 1994; Ferdu, 2009). Some of these insecticides such as the organophosphate methidathion are known to harm the natural enemies associated with WMS hence upset the natural biological control. Systemic
Sci. Technol. Arts Res. J., April-June 2015, 4(2): 59-63

insecticides with little or no harm to natural enemies of WMS are used elsewhere as an integral component of WMS Integrated Pest Management (IPM). One such insecticide is Spirotetratam (Movento) which belongs to the tetramic acid chemical class and has a unique mode of action classified as a lipid biosynthesis inhibitor (https:// www.bayercropscience.us/products/insecticides/movento (accessed on 21 October 2014). Hence, a preliminary survey on the distribution of the pest in available mango orchards in the central rift valley areas and assessment of efficacy of a Movento was made between June and October 2014 in CRV.

\section{MATERIALS AND METHODS}

\section{Survey on the Appearance of WMS in CRV}

Information on where to find mango trees in CRV were gathered from colleagues at MARC. A data sheet to record presence/absence of the pest, incidence and pest density was prepared. When presence of the pest was confirmed, leaf infestation level was determined by visual estimation of proportion of leaf infested. Estimation was made on whole tree basis as well as on lower branches of the tree only because of variation in with-in tree distribution of the pest. In infested fields, pest density was determined by counting colonies on the lower and upper sides of 3 leaf randomly picked (with eye closed) from the lower branches of up 10 randomly picked tree depending on tree availability. A colony consisted of a female WMS surrounded by males. A total of 17 mango orchards with a field size ranging between a tree and 24 ha were surveyed. Area names and GPS readings of the mango orchards surveyed are presented in Table 1. Descriptive statics was used to show mean leaf infestation and pest density of WMS infested orchards.

Table 1: Location details of mango orchards visited for White mango scale infestation in Central Rift Valley, August 2014

\begin{tabular}{|c|c|c|c|c|}
\hline $\begin{array}{c}\text { Field } \\
\text { no. }\end{array}$ & Area name & Location & Varieties & Field size \\
\hline 1 & Nura Era (Camp 11) & $08^{0}, 42^{\prime}, 28.5^{\prime \prime} \mathrm{N} ; 039^{0}, 47^{\prime}, 07.2^{\prime \prime} \mathrm{E}$ & Kent, Tommy, Local, Kit & 30 ha \\
\hline 2 & Nura Era (Camp 10) & $08^{0}, 43^{\prime}, 35.2^{\prime \prime} \mathrm{N} ; 039^{\circ}, 47^{\prime}, 42.2^{\prime \prime} \mathrm{E}$ & Kent, Tommy, Local, Kit, Dodo & 24 ha \\
\hline 3 & Nura Era (camp 8) & $08^{0}, 40^{\prime}, 44.7^{\prime \prime} \mathrm{N} ; 039^{\circ}, 47^{\prime}, 44.1^{\prime \prime} \mathrm{E}$ & Tommy, Kent & 48 ha \\
\hline 4 & Abadiska & $08^{0}, 34^{\prime}, 07.6^{\prime \prime} \mathrm{N} ; 039^{\circ}, 40^{\prime}, 16.0^{\prime \prime} \mathrm{E}$ & Tommy, Kent, Tawla, Local,Aabadir & 98 ha \\
\hline 5 & Koka Beri (Genet farm) & $08^{0}, 23,49.2^{\prime \prime} \mathrm{N} ; 039^{\circ}, 01^{\prime}, 07.9^{\prime \prime} \mathrm{E}$ & Some are apple mango grafted & Over 100 trees \\
\hline 6 & Alemtena (Kentari) & $08^{0}, 20^{\prime}, 22.4^{\prime \prime} \mathrm{N} ; 038^{0}, 59^{\prime}, 06.7^{\prime \prime} \mathrm{E}$ & Local old trees & Over 150 trees \\
\hline 7 & Meki Catholic) & $08^{0}, 09^{\prime}, 28.2^{\prime \prime} \mathrm{N} ; 038^{\circ}, 49^{\prime}, 10.4^{\prime \prime} \mathrm{E}$ & Unknown & Over 50 trees \\
\hline 8 & Meki (Wolda Kelina) & $08^{0}, 07^{\prime}, 21.6^{\prime \prime} \mathrm{N} ; 038^{0}, 51^{\prime}, 28.9^{\prime \prime} \mathrm{E}$ & Toommy atkin, kent, Appple mango & Over 50 trees \\
\hline 9 & Zeway (AAU campus) & $07^{0}, 56^{\prime}, 13.6^{\prime \prime} \mathrm{N} ; 038^{0}, 43^{\prime}, 09.6^{\prime \prime E}$ & Local old and tall varieties & Over 10 trees \\
\hline 10 & Zeway Prison & $07^{0}, 56^{\prime}, 25.2^{\prime \prime} \mathrm{N} ; 038^{0}, 42^{\prime}, 54.1^{\prime \prime} \mathrm{E}$ & Unknown & Over 100 trees \\
\hline 11 & Wonji Melkahida & $08^{0}, 29^{\prime}, 09.8^{\prime \prime N} ; 039^{0}, 13^{\prime}, 56.5^{\prime \prime} \mathrm{E}$ & Local old and tall varieties & Over 100 trees \\
\hline 12 & Wonji Sugar factory & $08^{0}, 27^{\prime}, 08.8^{\prime \prime} \mathrm{N} ; 039^{0}, 13^{\prime}, 52.9^{\prime \prime} \mathrm{E}$ & Local old and tall varieties & Homestead (2-3) \\
\hline 13 & Batu Degaga & $08^{0}, 26^{\prime}, 02.1^{\prime \prime} \mathrm{N} ; 039^{0}, 24^{\prime}, 40.1^{\prime \prime} \mathrm{E}$ & Local old and tall varieties & 28 trees \\
\hline 14 & Batu Degaga & $08^{0}, 25^{\prime}, 43.1^{\prime \prime} \mathrm{N} ; 039^{0}, 24^{\prime}, 41.1^{\prime \prime E}$ & Local old and tall varieties & One tree \\
\hline 15 & Batu Degaga & $08^{0}, 25^{\prime}, 38.5^{\prime \prime} \mathrm{N} ; 039^{\circ}, 24^{\prime}, 42.7^{\prime \prime} \mathrm{E}$ & Local old and tall varieties & Three trees \\
\hline 16 & Batu Degaga & $08^{0}, 25^{\prime}, 36.7^{\prime \prime N} ; 039^{0}, 24^{\prime}, 47.4^{\prime \prime} \mathrm{E}$ & Local old and tall varieties & Six trees \\
\hline 17 & Batu Degaga & $08^{0}, 25^{\prime}, 29.7^{\prime \prime} \mathrm{N} ; 039^{0}, 24^{\prime}, 12.6^{\prime \prime} \mathrm{E}$ & Local old and tall varieties & four trees \\
\hline
\end{tabular}

\section{Screening of Insecticides}

The experiment was conducted at Melkawoba, where heavy infestation was first noticed in CRV. The test insecticide, Movento was obtained from Bayer chemical company in Addis Ababa. Methidathon which is a registered insecticide for Red scale control on citrus in Ethiopia (MOA 2013) was obtained from Markos General
Chemical trading in Addis Ababa. The two insecticides along with the untreated plot were laid in RCBD with three replication. Because the available mango trees of uniform size were eleven, nine mango trees were selected for application of the treatments. Before applying treatments, the volume of water required to fully wet the experimental trees using motorized sprayer was calibrated. Three liters 
Gashawbeza Ayalew et alo,

of water per tree was found to be sufficient. The test insecticide Movento was applied at $1.7 \mathrm{ml}$ per tree. Methidathion was applied at $5 \mathrm{ml}$ per tree. Treatments were applied for a total of six times biweekly starting from August 20, 2014 using motorized knapsack sprayer. Ten leaves were randomly picked from the lower branch of each tree prior to treatment application to count WMS number. These were kept in a plastic bag and transported to MARC entomology laboratory for count. Number of male, female and crawlers WMS were counted using a stereoscopic microscope. Mean number of insects from post treatments spray were used to assess the efficacy of the insecticides. Data were analyzed using Proc ANOVA of SAS (SAS 1991). Significant means were separated using students Newman Keuls test. Abbott's (1925) formula was also used to determine corrected mortality after each treatment application.

Corrected mortality $=\left(1-\frac{\mathrm{n} \text { in T after treatment }}{\mathrm{n} \text { in Co after treatment }}\right) * 100$

Where $\mathrm{n}$ in $\mathrm{T}=$ Population in the treated plot after treatment; $\mathrm{n}$ in $\mathrm{Co}=$ Population in control after treatment
Sci. Technol. Arts Res. J., April-June 2015, 4(2): 59-63

\section{RESULTS}

Survey on the Appearance of WMS in CRV

Four out of 17 fields surveyed were found infested (excluding Melkawoba site with $100 \%$ WMS infestation). These areas are located at Batu degaga about ten to fifteen $\mathrm{km}$ east of MARC. Two of the orchards here were $100 \%$ infested (Table 2). Here, leaf infestation on lower branches (and whole tree) basis ranged between 7 and 85 (3 and 40). Number of colonies per 3 leaf ranged between 3 and 44. One mango tree located about $500 \mathrm{~m}$ away from the mango orchard with $100 \%$ WMS infestation $\left(08^{\circ} 25^{\prime} 43.1^{\prime \prime} \mathrm{N}\right.$ and $\left.039^{\circ} 24^{\prime} 41.1^{\prime \prime E}\right)$ did not show any symptom of WMS infestation. On the other hand, two fields with 4 and 6 mango trees had slight infestation (one to two leaf per field with WMS infestation). Block number C6 and C7 of camp 10 with a total area of 30 ha and camp 10 with an area of 24 ha at Nura era did not show symptom of WMS infestation. Mango trees of camp 8 at Nura era and Abadiska at Merti were also surveyed and no WMS infestation was observed. The insect was not found in the rest of the survey fields located between Wonji and Zeway too (Table 2).

Table 2: Presence of WMS and level of infestation in mango orchards located in CRV, 2013

\begin{tabular}{cccccc}
\hline \multirow{2}{*}{$\begin{array}{c}\text { Field } \\
\text { number }\end{array}$} & $\begin{array}{c}\text { Presencel } \\
\text { absence } \\
\text { of WMS }\end{array}$ & Status & \multicolumn{2}{c}{ Leaf infestation } & WMS density \\
\cline { 4 - 6 } 1 & Absent & $\mathrm{NI}$ & - & - & - \\
2 & Absent & $\mathrm{NI}$ & - & - & - \\
3 & Absent & $\mathrm{NI}$ & - & - & - \\
4 & Absent & $\mathrm{NI}$ & - & - & - \\
5 & Absent & $\mathrm{NI}$ & - & - & - \\
6 & Absent & $\mathrm{NI}$ & - & - & - \\
7 & Absent & $\mathrm{NI}$ & - & - & - \\
8 & Absent & $\mathrm{NI}$ & - & - & - \\
9 & Absent & $\mathrm{NI}$ & - & - & - \\
10 & Absent & $\mathrm{NI}$ & - & - & - \\
11 & Absent & $\mathrm{NI}$ & - & - & - \\
12 & Absent & $\mathrm{NI}$ & - & - & - \\
13 & Present & High & 50.2 & 18.8 & 18.1 \\
14 & Absent & Absent & - & - & - \\
15 & Present & High & 48.3 & 12.3 & 27.3 \\
16 & Present & slight & one leaf & one leaf & one leaf \\
17 & Present & slight & two leaf & two leaf & two leaf \\
\hline
\end{tabular}

\section{Insecticide Screening}

Mean number of WMS per ten leaves prior to the first treatment application was 702, 572 and 483 in Movento, Methidathion, and untreated treatments, respectively. Counts after the first treatment were similar for all the treatments including the untreated trees. Differences in WMS number between treatments began to be observed after the second spray although these differences were not significant until the fourth spray. Counts after the fifth spray and mean number of the counts after each spray showed significant difference between treatments (Figure
1). Number of WMS in the untreated tree was 8 to 10 fold over both Methidathion and Movento treatments after the fifth spray. Similarly, the overall mean in the untreated tree was triple over both Movento and Methidathion treatments. Performance of Movento in reducing the insect number was on par with Methidathion in each post spray count without a significant difference between them (Figure 1). Percent corrected mortality showed a progressive increase from 36 to $90 \%$ and 49 to $74 \%$ in Movento and Methidathion treatments respectively after the second to fifth spray (Figure 2). 

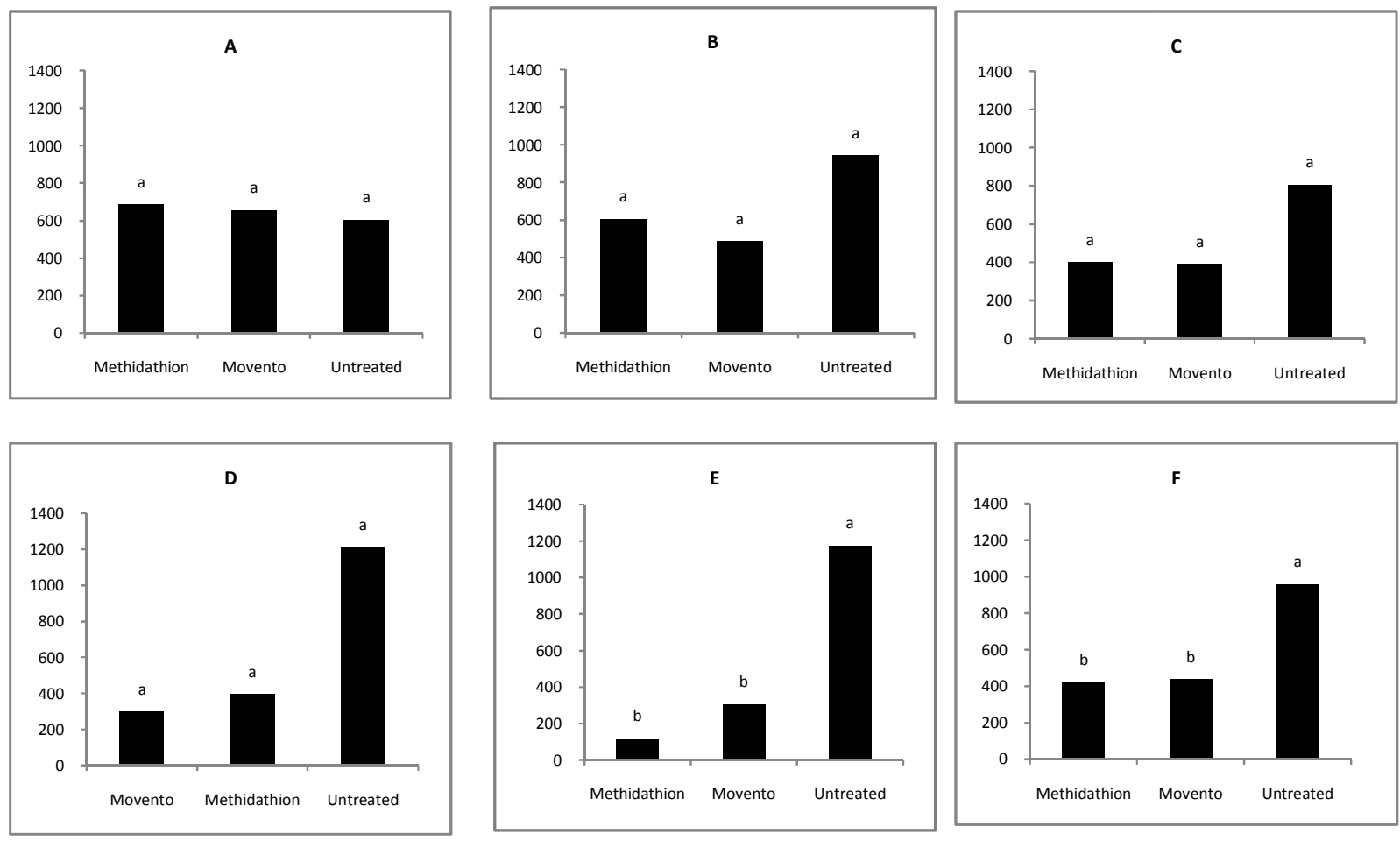

Figure 1: A, B, C, D and E shows the sum of male, female and crawlers of white mango scale for each treatment after the first, second, third, fourth and fifth sprays respectively; $F$ is the mean of the five counts after spray

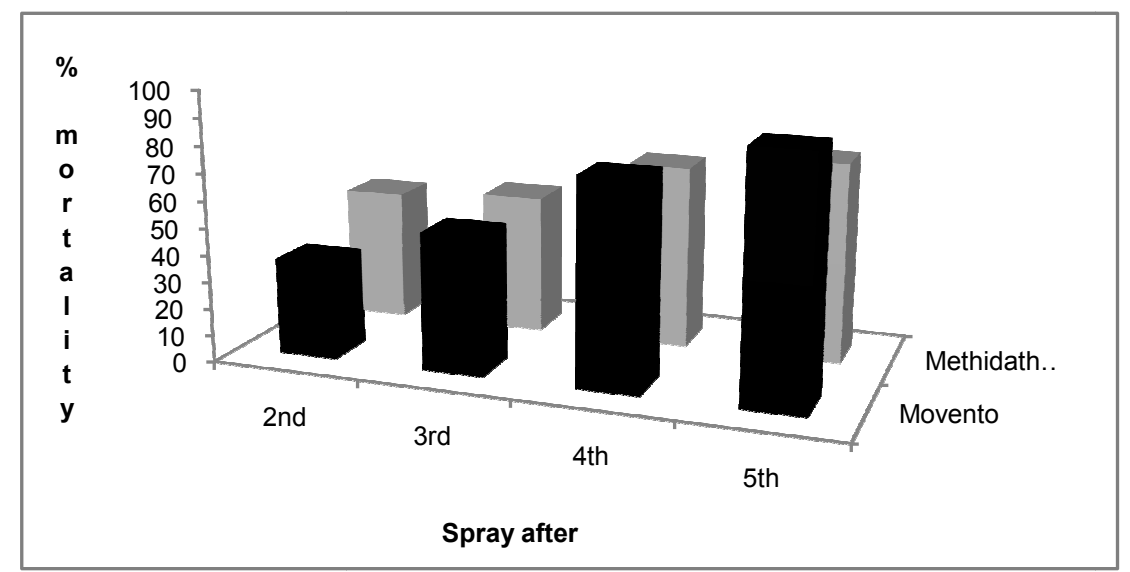

Figure 2: Percent corrected mortality of WMS based on Abbott's (1925) formula on Movento and Methidathion treated mango trees

\section{DISCUSSION}

WMS has now appeared in CRV although it is currently confined to pocket areas close to MARC. All the trees at Batu Degaga and about half of the trees at Melkwoba weree old and tall (about $10 \mathrm{~m}$ ) local varieties. According to owners of these orchards, these fields have never been sprayed with any pesticide since their establishment. New mango seedlings were not introduced to these areas until the presence of the pest was confirmed. Being a scale insect, its natural spread without human involvement is minimal. We do not presume to speculate reasons for its occurrence in these areas but the pest introduction to the country is likely to be with planting materials or fruits that are hosts to WMS. Besides mango, several plant species including citrus, papaya, avocado ginger, cinnamon, pumpkin etc., are hosts to $A$ tubercularis (http://www.plantwise.org/KnowledgeBank/ Datasheet.aspx). The pest is Asian origin and distributed all over the world. CABI distribution map of pests show that $A$. tubercularis occurs in several countries of west Africa and African countries south of Ethiopia including east African countries, Uganda, Kenya and Tanzania (http://www. plantwise.org/KnowledgeBank/Datasheet.asp $\mathrm{x}$ ). Although its occurrence in Ethiopia was noted as early as 2010 (Mohammed et al., 2012), Ethiopia is not included in the distribution map of this insect yet. The presence of the insect in a radius of $100 \mathrm{~km}$ from the major mango producing farm of the country presents great challenge to the mango industry as it can affect one of the biggest mango orchards of the country, Horizon plantation of UAAIE. It also hampers the current effort of 
Gashawbeza Ayalew et alo,

expanding mango production through supply of improved seedlings to small scale farmers in the CRV and other potential areas of the countries. Strengthening internal quarantine to limit the geographic expansion of the pest to newer area should be given emphasis by concerned government offices particularly regional agricultural bureaus. Several thousand seedlings purchased from Arbaminch area for plantation in Tigray were destroyed following suspicion of WMS presence in the seedling followed by its confirmation in 2014 (Gashawbeza, 2014). The pest is now established in different areas of the country. A country wide periodic survey on distribution of WMS on mango and other hosts need to be conducted to delimit areas for intervention. Only Movento is tested in the insecticide efficacy testing experiment reported in this paper. Spirotetramat (Movento) is a folliar-applied insecticide with ambimobile translocation that reduces fecundity of sucking insects which feed on roots as well as foliage (Smiley et al., 2011). Its performance was found to be comparable with the registered insecticide Methidathion. The observed slightly higher number of WMS in Movento compared to Methidathion after the first spray and lower number of the WMS in Movento treated trees than Methidathion treated in later samplings is similar to reports of Labanowska et al. (2014). Labanowska et al. (2014) reported similar or slightly poorer performance one week after application of spirotetramat against wheat aphids compared to standard insecticide, but 3 weeks after a higher reduction of aphids than with reference insecticides such as pirimicarb, thiacloprid, and thiamethoxam was recorded.

As Methidathion has been in use for several years against the Red scale, Aonidiella aurantii (Maskell), in Ethiopia, testing the efficacy of the new insecticide against Red scale is useful to mitigate problem associated with pesticide resistance as well as to strengthen biocontrol based integrated pest management in fruit crops. From laboratory and field studies conducted to measure the effect of spirotetramat on life stages of red scales, both organophosphate-resistant and susceptible populations responded similarly to the insecticide suggesting absence of cross resistance (Garcerá et al., 2013). It has been reported (Mohammed et al., 2012) that commercial farms and government offices use a variety of broad spectrum insecticides to reduce the pest's damage in western Ethiopia. The use of old broad spectrum insecticides for controlling WMS should be discouraged as they are ineffective in most cases and negatively affect the natural enemy population that aid in the natural control of the pest. Selective IPM compatible products need to be screened for use to promote biocontrol based management of the pest. Successful classical bio-control of WMS has been implemented in South Africa using the Aphelinid parasitoid, Aphytis chionaspis Ren (Daneel and Joubert, ND).

\section{CONCLUSION}

The results reported in this study confirmed presence of white mango scale (Aulacaspis tubercularis) in the CRV and efficacy of Movento against the pest. A study towards integrated management of the pest based on understanding the ecology of the pest including geographic distribution, and population dynamics need to be conducted. Insecticide screening program should focus on those that are less harmful to the pest's natural enemies.
Sci. Technol. Arts Res. J., April-June 2015, 4(2): 59-63

\section{Conflict of Interest}

Conflict of interest none declared.

\section{REFERENCES}

Abbott, W.S. (1925). A method of computing the effectiveness of an insecticide. Journal of Economic Entomology 18: 265-267.

Abo-Shanab, A.S.H. (2012). Suppression of white mango scale, Aulacaspis tubercularis (Hemiptera: Diaspididae) on mango trees in El-Beheira Governorate. Egyptian Academic Journal of Biological Sciences 5(3): 43-50

Central statistical Authority (CSA) (2012). Agricultural sample survey for $2005 \mathrm{EC}$.

Daneel, M.S., Joubert, P.H. (ND). Biological control of the mango scale Aulacaspis tubercularis Newstead (Hemiptera: Diaspididae) by a parasitoid Aphytis chionaspis Ren (Hymenoptera: Aphelinidae). ISHS Acta Horticulturae 820: VIII International Mango symposium (www.actahort.org/books/820/820_72.htm).

Ferdu Azerefegne., Mohammed Dawd., Difabachew Belay., Bezawork Mekonen (2009). Review of Entomological Research on fruit crops in Ethiopia. In: Abraham Tadesse (ed.). Pp. 69-92, Increasing Crop Production through Improved Plant Protection- Volume II. Plant Protection Society of Ethiopia (PPSE). PPSE and EIAR, Addis Ababa Ethiopia

Gashawbeza Ayalew (2014). Field trip report to Melkassa center of EIAR on Appearance and distribution of white mango scale in central rift valley region, Aug 2014, pp.9.

Garcerá, C., Ouyang, Y., Scott, S.J. Moltó, E., GraftonCardwell E.E. (2013). Effects of Spirotetramat on Aonidiella aurantii (Homoptera: Diaspididae) and Its Parasitoid, Aphytis melinus (Hymenoptera: Aphelinidae). Journal of Economic Entomology 106(5): 2126-2134.

Labanowska, B.H., Korzeniowski, M. and Gasparski, T. (2014). Efficacy of spirotetramat in the control of the currant-sowthistle (Hyperomyzus lactucae L.) on blackcurrant plantations in Poland. Journal of Horticulture Research 21(2): 73-78.

Mohamed, A.S. (2003). Biology, host and Host Plant Relationship of two Psyttalia species (Hymenoptera: Braconidae): Parasitoids for Fruit Flies (Diptera: Tephritidae) in Kenya. Ph.D. Thesis, University of Gezira.

Ministry of Agriculture (MOA) (2013). List of registered pesticides in Ethiopia as of January 2013, Animal and Plant Health Regulatory Directorate, Addis Ababa.

Mohammed Dawd., Belay H/Gabriel., Lemma Ayele., Konjit Feleke., Seyoum Hailemariam., Teshome Burka. (2012). White mango Scale: A new Insect Pest of Mango in Western Ethiopia. pp 257-267 In Eshetu Derso (eds.) Proceedings of the 3rd Biennial Conference of Ethiopian Horticultural Science Society, 4-5 Feb 2011, Addis Ababa, Ethiopia.

Plant Protection Society of Ethiopia (PPSE) (2013). Plant quarantine: the state of affairs in Ethiopia, Book of abstracts and programmes, 2oth Annual conference of PPSE, 25-26 December 2013, EIAR, Addis Ababa

SAS Institute (1999). SAS/STAT. The SAS system for windows, version 8.0, SAS Institute, Cary, NC.

Smiley, R.W., Marshall, J.M. and Yam, G.P. (2011). Effect of Foliarly Applied Spirotetramat on Reproduction of Heterodera avenae on Wheat Roots. Plant Disease 95(8): 983-989

Tsedeke Abate (1994). Entomological studies on fruit crops. In Herath and Lemma (eds.), Horticultural research and Development in Ethiopia. P 177-186, 1-3 Dec 1992, Addis Ababa Ethiopia. 